University of Warwick institutional repository

This paper is made available online in accordance with

publisher policies. Please scroll down to view the document

itself. Please refer to the repository record for this item and our

policy information available from the repository home page for further information.

To see the final version of this paper please visit the publisher's website. Access to the published version may require a subscription.

Author(s): Steve Fuller

Article Title: THE GENEALOGY OF JUDGEMENT: TOWARDS A

DEEP HISTORY OF ACADEMIC FREEDOM

Year of publication: 2009

Link to published version:

http://dx.doi.org/ 10.1111/j.1467-8527.2009.00434.x

Publisher statement: "The definitive version is available at www.blackwell-synergy.com" 


\section{THE GENEALOGY OF JUDGEMENT: TOWARDS A DEEP HISTORY OF ACADEMIC FREEDOM Steve Fuller}

I am a strong believer in the classical conception of academic freedom. It is an idea of quite specific historical, cultural and legal origins to which at least lip service has been paid by institutions of higher education worldwide. The idea is not only quite specific but also inherently controversial. Both of these points come through clearly if the concept of academic freedom is understood in terms of what has happened to the concept of judgement over the past two centuries. A robust sense of academic freedom has been historically associated with a distinctive sense of judgement as a mental faculty. The fates of the two concepts have basically risen and fallen together. In what follows, I develop this point from various angles, which I describe as the 'philosophical', 'religious' and 'sociological' sources of judgement and academic freedom. To be sure, the sources are overlapping but together they provide a glimpse to a mind-set that even in its heyday was highly volatile and which today we may be in danger of losing altogether.

\section{The Philosophical Sources of Judgement and Academic Freedom}

'Academic freedom' refers to a system of complementary rights and obligations entitled to teachers and students as free inquirers. It is rooted in the late Roman legal classification of universities with guilds, churches, monastic orders and city-states as indefinitely self-reproducing, self-governing social entities dedicated to activities whose value transcends the interests of their current practitioners (Fuller 2000a: chap. 4). Even in the $13^{\text {th }}$ century the idea was controversial because members of such corporate bodies were largely immune from laws to which they would have been normally subject as members of particular families or residents of particular fiefdoms. But the level of controversy was raised further when academic freedom was made the cornerstone of the modern national university by Wilhelm von Humboldt in 1810. In the first instance, this move enabled theology to be pursued as Wissenschaft - systematic knowledge for its own sake without specifically pastoral concerns. The distinction is routinely enshrined today in the difference between a religious studies department in the arts or social sciences faculty and a free-standing divinity school that provides professional training for clerics of particular faiths.

In the first half of the $19^{\text {th }}$ century, the German university system was marked by continuous upheaval that left permanent traces on the face of Western scientific and political thought, a flavour of which can be still obtained by reading Marx and Engels’ The German Ideology. All of this turned on the Kantian word that Humboldt used to characterise the exercise of academic freedom: 'judgement', or Urteil. Philosophers will be most familiar with Urteil as the guiding concept of Kant's third critique, which is concerned with aesthetic and teleological judgement. Humboldt (1988) took seriously Kant's claim that the mind's spontaneous capacity for judgement provides the backdrop against which formal reasoning develops: Initially we think logically because we need to judge between alternative configurations of the manifold of experience that attracts our attention. However, our power of discrimination is not free unless we can adopt a position from which to think about the alternatives that does not reflect any dependency on them: In other words, we can judge the alternatives in their own terms rather than based on how they impact on us. In ordinary German, Urteil is associated with the judge who issues a verdict and, where appropriate, 
pronounces a sentence in a trial, thereby resolving both the factual and the normative status of the case.

This legal context helps to illuminate the theologically controversial nature of Urteil In ancient Athens the judges were called hairetikoi, those with the power to decide the outcome of a case. They were not professional lawyers but more like jurors -- that is, citizens in good standing chosen for their neutrality to the case. The very need for such a figure drew attention to a schism that already existed in the community, as plaintiff and defendant each mobilised their supporting witnesses and advocates. Moreover, their disagreements may or may not be resolved by the decision taken by the hairetikos. Centuries later, in canon law, the idea morphed into the pejorative 'heretic', suggesting someone who actively promotes doctrinal schism. But why might the schism continue even after a judgement is passed? The answer goes beyond the theological and legal bases of Urteil to its roots in logic, where it refers to the activity of classifying something as belonging to a category for purposes of drawing a conclusion about it. In metaphysics, to issue a judgement is to subsume a particular under a universal. For example, in the famous Aristotelian syllogism, the judgement 'Socrates is mortal' is based on Socrates being categorised as a human being. Socrates could be categorised in any number of ways, each accessing properties that he shares with other beings. But in order to judge Socrates as mortal, he must be classed with humans -- or some still more universal category, such as animals.

The example highlights the peculiar combination of chance, freedom and necessity that constitutes judgements. First, one is thrown into an unresolved situation - the case of Socrates. Second, it is clear that Socrates can be understood in many different ways. Third, it is equally clear that if Socrates is to be understood as mortal, it must be because he is understood as human (or animal). Before the first decade of the $20^{\text {th }}$ century, when Bertrand Russell and Alfred North Whitehead, building upon the work of the German mathematician Frege, demonstrated the analytic power that was added to logic by an algebraic formalisation, logic was generally seen as a normative psychology concerned with the licensing of judgements in the sense we have been discussing. This sense of logic was sustained and developed throughout the $19^{\text {th }}$ and well into the $20^{\text {th }}$ century by philosophers influenced first by German idealism and then by American pragmatism, perhaps most notably by John Dewey in what many regard as his magnum opus, Logic: The Theory of Inquiry, which is now read as a treatise on the metaphysical foundations of problem-solving (Passmore 1966: chap. 7).

A vestige of Dewey's older way of thinking about logic remains in the concept of soundness, which in ordinary language is still regularly applied to judgements, as when we say someone 'exercises sound judgement'. However, this heritage is somewhat obscured in the lexicon of formal logic, where 'soundness' refers specifically to arguments that are not only deductively valid but also contain true premises. But what makes the premises of an argument true? Today's logician responds that the premise corresponds to the facts. After Alfred Tarski, 'correspondence' has acquired a technical meaning - namely, that 'Socrates is human' (the basis on which he is judged mortal) is true if and only if Socrates is indeed human (Passmore 1966: chap. 17). However to someone still wedded to judgement-based logic, this definition covers too much ground; it fails to respect the judge's discretion concerning the standpoint from which Socrates is to be understood for purposes of issuing a judgement. Thus, to accommodate the judge as free agent, the 'if' condition needs to be dropped from the Tarski definition of correspondence. In other words, the 
bare fact that Socrates is human would not imply an assertion of his humanity, unless the judge had decided it was relevant to the context in which Socrates is under judgement, in which case 'Socrates is human' obviously would be asserted.

What does any of this have to do with today's issues concerning academic freedom? For all its abstract simplicity, the above discussion highlights the ways in which truth, validity, soundness and relevance are bound together with not only so-called facts-of-the-matter, over which we might exert relatively little control, but also how we organize and respond to them, over which we can exert much more control. Academic freedom relies on the concept of judgement to sharpen the difference between these two perspectives, which in turn defines a domain in which academics may legitimately exercise their freedom. Put in contemporary terms, the focus on judgement makes it possible to assert both one's recognition of the brute facts and one's openness to alternative theories by which they may be understood. The contrasting state-of-affairs would be one in which facts are seen as already bearing their own interpretation, such that to recognize them properly is ipso facto to draw the appropriate conclusion. One would expect this latter stance as the official epistemology of a society dominated by religious orthodoxy or political ideology. The contrast brings out the amount of free play effectively allowed under the rubric of 'academic freedom' and perhaps helps explain its controversial character both in and out of academia.

A train of thought that has migrated from the philosophy of science to the larger intellectual culture over the past fifty years has obscured the significance of what is at stake here. It turns on the idea, originating in Hanson (1958) but popularised in Kuhn (1970), of 'theory-laden observation'. For many years it has been common to treat this phrase as an implicit license for relativism, reading it to mean that people will see only what their background beliefs allow them to see. No doubt this reading was influenced by Kuhn's notorious incommensurability thesis, which implied that scientists are so wedded to the theories in which they were trained that a generational change - that is, a cohort of scientists trained in a different theory - is necessary before a scientific revolution fully succeeds. In other words, scientists never change their minds simply on the basis of the facts. But that is only the negative side of theory-laden observation. The positive side is that the facts do not speak for themselves but require a theory for their articulation. The license to produce such a theory is what academic freedom protects, as it requires passing judgement on what are the essential and accidental features in a given domain.

Here it is worth recalling the trivialisation of the idea of 'value judgement' as it migrated from German to English academic discourse in the $20^{\text {th }}$ century. Nowadays value judgements are seen as aspects of one's personal experience that are brought with mixed feelings to the research and teaching environment. They both enable and disable the observation of certain things. Value judgements are a sign of the researcher's subjectivity and a potential contaminant to an objective appraisal of what is under investigation. Attitudes towards value judgements vary wildly in research methods textbooks: Positivists fear bias and distortion, while postmodernists celebrate the giving of 'voice'. Without denying any of these points, the original German context placed the affirmation of value judgements in a more positive light - that is, as a defensible extension of academic freedom. I refer here to the widely misunderstood Werturteilstreit ('value-judgement dispute') that occurred in the first decade of the $20^{\text {th }}$ century, which resulted in the institutionalised separation of sociology from social policy in German academia (Proctor 1991: chap. 7). 
It was in the wake of the Werturteilstreit that 'value-judgement' and 'value-freedom' started to acquire international currency as constitutive of the academic ethos. In this context, Max Weber served as the point of reference for promoting these concepts, especially as his works were translated in English, courtesy of Edwards Shils and Talcott Parsons. However, lost in translation from Weber's original context, yet still relevant today, is the question of who should supply the values that inform the theoretical standpoint from which academic research is conducted. Weber and his sociology colleagues wanted that power to remain in the hands of the academics themselves - not the government. In this respect, the Werturteilstreit may have been the first organized academic protest against what we now call 'evidence-based policy', whereby academics simply act as sophisticated data collectors and analysts for projects whose intellectual horizons had been set by their political paymasters. This was certainly how the German 'social policy' academics were portrayed by Weber, who sarcastically labelled them 'socialists of the chair', since they were usually social democrats concerned with ameliorating the plight of labour to prevent the proletarian revolution from first happening in Germany, as Marx had predicted (Rueschemeyer and Van Rossem 1996).

But this did not mean that Weber and his like-minded 'sociologists' were apolitical. Nevertheless, a remarkable feature of Weber's many engagements in public discourse is that all of his comments - whether pro or con government policy - were stated so as not to jeopardize continued protection of academic freedom in this strong sense of enabling academics to set their own theoretical horizons. At the same time, Weber conjoined that right with the duty to permit 'value-free' tests of those horizons - that is, by evidence collected from a standpoint independent of the theorist. In other words, 'value-freedom' refers specifically to freedom from the values that inform the theory subject to validation. Another way to capture this sensibility is the distinction drawn by philosophers of science between the 'context of discovery' and the 'context of justification'. The latter is also 'value-free' insofar as one can establish the validity of a particular knowledge claim without having undergone the same set of experiences and sharing the same value assumptions as the original claimant (Fuller 2000b: chap. 1).

\section{The Religious Sources of Judgement and Academic Freedom}

I earlier noted that the classical conception of academic freedom, with its focus on the exercise of independent judgement, was a product of the modern German university. I also observed that the first test of this conception came with the separation of scientific (i.e. 'critical-historical') from pastoral theology. But another aspect of the religious origin of academic freedom is specifically denominational, reflecting its Protestant - not Catholic -- roots. Two features of Protestantism are relevent here.

To appreciate the first feature, consider that in the university's original Catholic environment, the relation between teacher and student was at least as much pastoral as 'instructional' in the strict academic sense. The teacher was the surrogate parent - 'in loco parentis' -- of the student who lived away from home on university grounds. However, by the time academic freedom came to be formalised in the early $19^{\text {th }}$ century, the relationship between teachers and students was defined as a system of complementary rights and duties, known as Lehrfreiheit (freedom to teach) and Lernfreiheit (freedom to learn). Teachers were obliged to open the minds of students to learning 
without in the process indoctrinating them to a particular world-view (Metzger 1955). The focus here was the very Protestant one of clearing a space so that the student can freely decide what to believe - or at least what is important to learn. The most obvious, albeit not most imaginative, pedagogical route is for the teacher to present the student with several options on a given matter, including with their strengths and weaknesses but without drawing an authoritative conclusion. But as Max Weber (1958) reminded graduate students in his famous lecture, 'Science as a Vocation', this focus is always tricky to maintain in practice. An important waystation between the old pastoral view of the teacher-student relationship and this stark 'decisionism' of the modern university was the Jesuit idea of cura personalis, in which the teacher serves as the student's 'companion', trying to awaken in him a 'life in Christ' by appealing to the student's own intellectual and psychic resources but ultimately leaving the decision up to him.

The second feature of the classical conception of academic freedom that marked a shift from Catholicism to Protestantism is that the modern German university professor was more like a minister of a church than a monk in a monastery: The professor found the spark of the divine within himself, as opposed to looking to the demigods of his discipline for guidance. The corresponding mode of institutional being was charismatic rather than collegial: German professors attracted students and created fiefdoms that might evolve into disciplines, as opposed to, say, their Oxbridge counterparts, who were preoccupied with collective self-governance and displayed little interest in proselytism (Clark 2006).

Set against this institutional context, 'judgement' acquires an additional depth of meaning, which relates to what is ideally transmitted from teacher to student. The answer implied in the idea of Lernfreiheit is not mastery of a doctrine but the capacity to judge what is worth learning. It consists of adopting the attitude, though not necessarily the content, exemplified by the professor. Students incapable of 'striking the pose' of professorial authority for themselves remain in a state of 'nonage', that is, someone who waits for others to tell them what to think - as Kant famously characterised the pre-Enlightenment mind. In this respect, the sense 'judgement' promoted by academic freedom is tied to the promotion of subjectivity that first came into its own with early $19^{\text {th }}$ century Romanticism. Schelling and Hegel set precedents for the Romantic expression of academic freedom in the natural and social sciences, respectively. Their most lasting legacy to this discussion is the idea that the point of the university is to unify knowledge in a way that renders it comprehensible to a single human mind, an aspiration of the curriculum that is underwitten by our having been created in the image and likeness of God. Humboldt's Kant-inspired innovation here was to replace dogmatic theology with critical philosophy as the secular source of pedagogical unity.

Both naturalistic and humanistic traces of this 'unitarian' impulse remain in contemporary academic life and, perhaps predictably, test the limits of academic freedom. On the humanistic side, there have been perennial and invariably polemical debates over 'the canon', that is, the finite number of 'great books' that anyone should master in order to be 'liberally educated'. In the United States, where students generally are not required to select a major subject until half-way through their undergraduate education, debates over the canon have become totemic rituals, whereby academics bear witness to their calling and challenge others who appear to bear false witness. Elsewhere in the world, where students are expected to specialise much earlier in their academic careers, debates over the canon have turned into a staple of the public intellectual 
literature, in which academics contest the merits of various would-be classics with journalists and politicians who might have been once their students. On the naturalistic side, there is the equally controversial - and popular - preoccupation with 'grand unified theories of everything'. Although this quest derives its impetus from physics, the same ambition has applied to the 'Neo-Darwinian synthesis' in biology since the 1940s (Fuller 2007: chap. 2). Here the sense of unity consists of the ability of understanding the widest range of phenomena by appealing to the smallest set of general principles.

The striking point here - which makes the German idealists and the logical positivsts strangely natural bedfellows - is the significance of reduction in both the humanistic and naturalistic instances of unity. An interesting transitional figure between the idealists and the positivists was Emil DuBois-Reymond, a leading late $19^{\text {th }}$ century physiologist and intellectual descendant of Schelling who popularised the idea of natural scientists as exemplars of academic freedom in his 1882 inaugural address as Rector of the University of Berlin, Humboldt's original base (Veit-Brause 2002). Where an idealist like Hegel exhorted academics to embody the 'world-historic spirit' (Geistesweltgeschichte) by determining what from other times and places belong to the emerging self-consciousness of humanity, DuBois-Reymond spoke of their dedicated search for causal explanations as the driving force of history (Causalitätstrieb). In any case, it is unlikely that unity would have become such an esteemed epistemic value if the individual human being qua free inquirer were not its locus of concern. After all, the value of unity lies not in the sheer recognition of reality as inherently unified (because that is not possible - and here the post-Kantians defer to the deity) but in the active construction of a unified vision of reality as indicative of one's autonomy.

In this context, the shibboleth 'reductionism' should be understood somewhat more charitably as referring to the autonomous person's capacity to discriminate the wheat from the chaff in the phenomena he or she faces: What is causally relevant or explanatorily deep, as opposed to merely a striking accident or persuasive observation? One takes responsibility for the answers given to such questions by articulating a Weltbild (literally 'world construction') that attempts to make sense of them. Of course, it is to be expected that other autonomous indviduals operating from different Weltbilder will contest these judgements - and in the context of these trials the significance of 'value-freedom' becomes clear. However, matters got complicated at the dawn of the $20^{\text {th }}$ century, when for various intellectual and political reasons physicists following Max Planck started to advocate that all members of the same academic discipline should adopt the same Weltbild, what Kuhn later popularised as 'paradigm' (Fuller 2000b: chap.2). Thereafter, the distinction between being 'original' and being 'crackpot' started to acquire a salience within academia that it had previously lacked, as peer-based intellectual conformity came to be seen as a strength rather than a weakness.

Although Schelling and Hegel left stronger imprints in the development of the special sciences, the self-expressive ideal of academic freedom highlighted above was most explicitly embodied in their older contemporary, Johann Gottlieb von Fichte. In Fichte's spoken and written work the various strands supporting this ideal were brought together - including the original philosophical defense of authorial copyright in publishing. This he presented as the legal recognition of intellectual freedom - a radical move in a country that lacked the generalised freedom of expression underwritten in the recently enacted US Bill of Rights. In effect, Fichte argued that 
authors added something unique beyond the sheer physical labour of writing about a topic that deserved legal protection - namely, the distinctive stance they adopt towards the topic, as reflected in their unique mode of expression (Woodmansee 1984). Behind this conception lay the sense that self-assertion is by no means natural. On the contrary, it is an endless struggle (Sturm und Drang) against conformity to nature, especially submission to animal appetites. Speaking one's mind and fiinding one's voice is hard work -- and deserves to be rewarded accordingly -- because one is always navigating between the Scylla of the herd mentality and the Charbydis of perverse contrarianism. Both are 'instinctive responses' that let others determine my own beliefs -- in the latter case, I simply believe the opposite of whatever most others believe. Thus, they abandon the rational self-determination that is at the heart of academic freedom.

Of course, as the histories of both Protestant Christianity and German academia demonstrated all too well, the price of encouraging such independence is fractiousness, as students are effectively encouraged to outgrow their teachers, especiallly at the postgraduate level, where the stress is placed on 'originality' as the mark of research worthy of academic certificiation. Indeed, students' own sense of charisma may extend to believing that they are are better positioned to take forward a common body of knowledge than the professors from whom they learned it. The result is a proliferation of 'schools', academia's version of churches that make it difficult to maintain the transgenerational, de-personalised sense of 'discipline' associated with monasticism. To be sure, academics continue to be reminded of this suppression of academic subjectivity in, say, the restricted use of personal names to refer to experimentally generated 'effects' but not general principles of nature and, more generally, the hermeneutically casual, if not irresponsible, stance that especially natural scientists are encouraged to adopt towards the 'literature' to which they contribute. The ease with which articles that have never been read, let alone read in context, attract huge citation counts speaks to an academic culture that is trying its hardest to erase any interest in the author when assessing knowledge claims (Fuller 1997: chap. 4).

\section{The Sociological Sources of Judgement and Academic Freedom}

It is worth observing that throughout academic freedom's turbulent German history, it was never assumed that academics themselves were its most reliable guardians. The temptation of professors to indoctrinate, if not outright anoint, the successors to their chairs, matched by a willingness of their students to succumb to such treatment as a means of securing and enhancing professional status, always threatened to create academic dynasties. It is normally conceded that Bismarck's long-serving minister for higher education, the political economist Friedrich Althoff, managed to propel Germany to the top spot of scientific powers by 1900 by deciding on all professorial appointments himself, drawing on a largely confidential network of international advisors. The resulting decisions often went against local wishes, forcing ambitious academics to cash in whatever cultural capital they had amassed at their home institutions to play in Althoff's national lottery (Backhaus 1993). At the time Max Weber could see in the 'Althoff System' nothing more than a bald-faced government attempt to break the university's historic right to self-determination (Shils 1974). But with the benefit of hindsight it has become clear that the minister's policies resulted in an unprecedented cross-fertilisation of ideas and approaches that enriched the emerging special sciences, a nationwide conception of intellectual competition that led to an overall raising of acadeimic standards across institutions (Fuller 2008). 
An interesting, albeit ironic, example of the long-term effect of the Althoff System is the emergence of psychology as an academic discipline in the final quarter of the $19^{\text {th }}$ century. The case is interesting because a long-term consequence of the various chairs and schools in psychology established in this period is that judgement, the mental faculty most closely associated with academic freedom, came to lose its salience as an object of systematic inquiry. In a nutshell, psychology emerged as a discipline in Germany as ambitious people trained in medicine, a highly competitive field, were forced to migrate to philosophy, a relatively uncompetitive field, in order to secure professorships. Once ensconced, they could then render traditional philosophical questions (e.g. the mind-body problem) tractable by the latest medical instruments and techniques (Ben-David and Collins 1966). How exactly this development led to the demise of the mental faculty of judgement is quite complex, but the overall consequence is clear: 'Judgement' is among relatively few terms that over the past century has lost, rather than acquired, technical meaning. In the past, the possession of 'judgement' implied a need for training, whether it be in logic, art or law. Today no such training is implied.

One way to appreciate what happened is that the separation of psychology from philosophy helped to split the concept of judgement apart (Kusch 1999). On the one hand, philosophy came to concern itself with the purely logical side of judgement, namely, the adoption of pro- and conattitudes to propositions, which by the early $20^{\text {th }}$ century, under Frege's influence, had evolved into the formal assignment of truth values, which in turn could be mechanically manipulated as algebraic formulae. On the other hand, psychology initially focused more on the phenomenology of thinking, in which judgement came to be reduced to the bare process of directing one's attention to a task set by the experimenter. Moreover, as experimental psychology became methodologically more rigorous, doubts were raised as to the very existence of an experience of thinking distinct from the contents of thoughts. Meanwhile what had dropped out from this split concept of judgement was the sense that an autonomous subject had decided to, say, assert a proposition or solve a problem. Both philosophers and psychologists, in their newly professionalised guises, seemed concerned only with objects of thought and sites of thinking - not with the integrity of the thinker.

Corresponding to this intellectual splitting, especially after the First World War, was an institutional splitting of the concept of judgement. Indicative of this development was philosophy's gradual loss of salience as the foundational discipline for all university subjects. Following the lead of Max Weber, Karl Jaspers famously argued that academic specialisation meant that the sense of free inquiry promoted by 'science as a vocation' had to be now understood as something pursued within - not beyond - disciplinary boundaries (Ringer 1969: 105-7). Much of Weber's methodological writings can be understood as implicitly staking out this claim as he defended the borders of sociological inquiry from the 'higher order' encroachments of Lebensphilosophie, dialectical materialism and social energeticism. Nowadays a vulgarised version of the Weber-Jaspers argument has become standard in defining the limits of academic freedom - namely, that one is free to speak within one's expertise, but not beyond it. However, when the argument was first made in the 1920s, it served to destroy the soul of the classical German university, what Fritz Ringer has poignantly called 'the decline of the German mandarins'. Those who refused to accept Weber's respecification of the scope of academic freedom found themselves increasingly cast - sometimes willingly, sometimes not - as 
reactionaries who defended a nostalgic image of undergraduate liberal education against the alienated learning represented by the modern graduate school.

Although I have been primarily concerned in this essay with the German sources of academic freedom and judgement, the various debates, conflicts and tensions recounted here have had correlates elsewhere, often as explicit German imports, though the outcomes have not always been the same. In the case of the United States, a version of the Weber-Jaspers thesis was invoked by the American Association of University Professors to protect the tenure of social scientists whose theories and methods openly contradicted the political and religious beliefs of their academic employers. The results were mixed for the social scientists concerned but a long-term constructive consequence of this encounter was, starting in the 1930s, a rededication to general education at the undergraduate level as a counterbalance to the increasing significance of specialised graduate education. A bellwether figure here was University of Chicago President Robert Maynard Hutchins, who was by training a natural law theorist and hence steeped in the philosophical and religious sources of academic freedom. Although hardly a political radical himself, Hutchins (1953) was instrumental in keeping alive the broader 'trans-disciplinary' sense of academic freedom that originally animated Humboldt's vision and continued to inform the self-understandings of both American teachers and students well into the late $20^{\text {th }}$ century, not least in the 1962 Port Huron Statement that marked the founding of Students for a Democratic Society. I conclude with this reminder of Hutchins because, in the end, he was more effective in selling the broad sense of academic freedom to the American public than to his own academic constituents at the University of Chicago. But that rhetorical work was probably necessary to keep academic freedom as a value that not only academics have an interest in sustaining.

\section{References}

Backhaus, J. (1993) 'The University as an Economic Institution: The Political Economy of the Althoff System’. Journal of Economic Studies 20 (4/5): 8-29.

Ben-David, J. and Collins, R. (1966). "Social factors in the origins of a new science: The case of psychology," American Sociological Review. 31: 451-465

Clark, W. (2006). Academic Charisma and the Origin of the Research University. Chicago:

University of Chicago Press.

Fuller, S. (1997). Science. Milton Keynes UK: Open University Press.

Fuller, S. (2000a). The Governance of Science. Milton Keynes UK: Open University Press.

Fuller, S. (2000b). Thomas Kuhn: A Philosophical History for Our Times. Chicago: University of Chicago Press.

Fuller, S. (2007). New Frontiers in Science and Technology Studies. Cambridge UK: Polity. Fuller, S. (2008). 'Justifying science: The need for macroeconomic knowledge policy'. In G. Hearn and D. Rooney (eds.), Knowledge Policy: Challenges for the $21^{\text {st }}$ Century (Pp. 120-37) Cheltenham UK: Edward Elgar.

Hanson, N.R. (1958). Patterns of Discovery. Cambridge UK: Cambridge University Press. Humboldt, W.v. (1988). On Language. Cambridge UK: Cambridge University Press. Hutchins, R.M. (1953). The University of Utopia. Chicago: University of Chicago Press. Kuhn, T.S. (1970). The Structure of Scientific Revolutions. $2^{\text {nd }}$ edn. (Orig. 1962) Chicago: University of Chicago Press.

Kusch, M. (1999). Psychological Knowledge: A Social History of Philosophy. London: Routledge. 
Metzger, W. (1955). Academic Freedom in the Age of the University. New York: Random House. Passmore, J. (1966). A Hundred Years of Philosophy. $2^{\text {nd }}$ edn. (Orig. 1957) Harmondsworth UK: Penguin.

Proctor, R. (1991). Value-Free Science? Cambridge MA: Harvard University Press.

Ringer, F. (1969). The Decline of the German Mandarins. Cambridge, MA: Harvard University Press.

Rueschemeyer, D. and R. Van Rossem (1996). 'The Verein für Sozialpolitik and the Fabian Society: A Study in the Sociology of Policy-Relevant Knowledge'. In D. Rueschemeyer and T. Skocpol (eds.), States, Social Knowledge and the Origins of Modern Social Policies (Pp. 117-62). Princeton: Princeton University Press.

Shils, E. ed. (1974) Max Weber on Universities: The Power of the State and the Dignity of the Academic Calling in Imperial Germany Chicago, IL: University of Chicago Press.

Veit-Brause, I. (2002). 'The making of modern scientific personae: the scientist as a moral person? Emil Du Bois-Reymond and his friends'. History of the Human Sciences 15 (4): 19-49 Weber, M. (1958). 'Science as a Vocation' In. H. Gerth and C.W. Mills, eds. From Max Weber (eds.), pp. 129-58 (Orig. 1918). Oxford: Oxford University Press.

Woodmansee, M. (1984) "The Genius and the Copyright," Eighteenth Century Studies 17: 425-448. 